\title{
Prescribing patterns of Medicine ClAssified as 'ANTIDEPRESSANTS' in SOUTH AfricAN CHILDREN AND ADOLESCENTS
}

\section{Authors:}

Johanita R. Burger ${ }^{1}$

Elmarie van der

Westhuizen 1

Martie S. Lubbe

Jan H.P. Serfontein ${ }^{1}$

\section{Affiliations: \\ ${ }^{1}$ School of Pharmacy, North-West University (Potchefstroom Campus), South Africa}

\section{Correspondence to Johanita R. Burger}

e-mail:

johanita.burger@nwu. ac.za

\section{Postal address:}

Medicine Usage in South Africa (MUSA), School of Pharmacy, North-West University (Potchefstroom Campus), South Africa

\section{Keywords:}

antidepressants; South

African private health care sector; retrospective drug utilisation; prescribing patterns; prescribed daily dosages

\section{Dates:}

Received: 27 Oct. 2008 Accepted: 25 Feb. 2009 Published: 16 July 2009

\section{How to cite this article:} Burger, J.R., Van der Westhuizen, E., Lubbe, M.S. \& Serfontein, J.H.P., 2009, 'Prescribing patterns of medicine classified as 'antidepressants' in South African children and adolescents', Health SA Gesondheid 14(1), Art. \#453, 8 pages. DOI: $10.4102 /$ hsag.v14i1.453

\section{This article is available} at: http://www.hsag.co.za

(c) 2009. The Authors. Licensee: OpenJournals Publishing. This work is licensed under the Creative Commons Attribution License.

\begin{abstract}
The main objective of this study was to characterise prescribing patterns of medicine classified as 'antidepressants' (hereafter simply referred to as antidepressants) in children and adolescents in the private health care sector of South Africa. A retrospective drug utilisation design was used to identify patients aged 19 years and younger from a South African pharmaceutical benefit management company's database, whom were issued at least one antidepressant between 1 January 2006 and 31 December 2006. Prescribed daily dosages (PDDs) were calculated using the Statistical Analysis System ${ }^{\circledR}$ program. A total of 1013 patients received a mean number of 2.88 (SD 3.04) prescriptions per patient. Females received more prescriptions than their male counterparts, with the highest prevalence in the $15 \leq 19$ years age group. The pharmacological groups most prescribed were the selective serotonin reuptake inhibitors $(43.0 \%)$ and the tricyclics $(42.7 \%)$, with imipramine $(22.04 \%)$ and amitriptyline (19\%) as the most commonly prescribed drugs. Approximately $30 \%$ ( $n=2300)$ of all antidepressants in the study population were prescribed off-label. Amitriptyline and clomipramine were prescribed at daily dosages higher than recommended in children and adolescents aged $9 \leq 15$ years. Lithium, trimipramine, trazodone and sulpiride were prescribed at sub-therapeutic dosages in adolescents. This study provided insight in the prescribing patterns of medicine classified as antidepressants in South African children and adolescents. These drugs, however, have many indications. Further research is needed to determine reasons why specific drugs are prescribed in this population.
\end{abstract}

\section{OPSOMMING}

Die algemene doelstelling van hierdie studie was om die voorskrifpatrone van middels wat as 'antidepressante' geklassifiseer word (hierna verwys na as slegs antidepressante) wat vir kinders en adolessente in die Suid-Afrikaanse private gesondheidsorgsektor voorgeskryf word, te beskryf. 'n Retrospektiewe medisyneverbruiksontwerp is gebruik om pasiënte 19 jaar en jonger, wat in die periode van 1 Januarie 2006 tot 31 Desember 2006 ten minste een voorskrif vir ' $n$ antidepressant ontvang het, in die databasis van 'n Suid-Afrikaanse farmaseutiese voordelebestuursmaatskappy te identifiseer. Voorgeskrewe daaglikse dosisse (VDDs) is bereken deur van die program Statistical Analysis System ${ }^{\circledR}$ gebruik te maak. 'n Totaal van 1013 pasiënte het 'n gemiddeld van 2.88 (SA 3.04) voorskrifte per pasiënt ontvang. Vroue het meer voorskrifte as hul manlike eweknieë ontvang, met die hoogste voorkoms in die ouderdomsgroep $15 \leq 19$ jaar. Die farmakologiese groepe selektiewe serotonienheropnameremmers $(43.0 \%)$ en die trisikliese antidepressante $(42.7 \%)$ is die meeste voorgeskryf, met imipramien $(22.04 \%)$ en amitriptilien $(19 \%)$ as die mees algemeen voorgeskrewe middels. Ongeveer 30\% ( $n=2300)$ van alle antidepressante in die studiepopulasie is voorgeskryf vir indikasies waarvoor dit nie geregistreer is nie. Amitriptilien en klomipramien is teen daaglikse dosisse hoër as die aanbevole vir $9 \leq 15$-jarige kinders en adolessente voorgeskryf. Litium, trimipramien, trasodoon en sulpiried is teen sub-terapeutiese dosisse vir adolessente voorgeskryf. Hierdie studie het insig verleen ten opsigte van die voorskrifpatrone van middels wat as antidepressante geklassifiseer word vir Suid-Afrikaanse kinders en adolessente. Hierdie middels het egter baie gebruike. Verdere navorsing word benodig om redes te bepaal waarom sekere middels in hierdie populasie voorgeskryf word.

\section{INTRODUCTION}

The use of antidepressant drugs among children became a concern in October 2003 when health officials in Britain, France, Canada and the United States issued warnings that paroxetine - a popular selective serotonin reuptake inhibitor (SSRI) - might be associated with excess reports of suicidality in children and adolescents (Rosack 2003:1; United States Food and Drug Administration 2003). Soon after, the manufacturer of venlafaxine - a selective serotonin and noradrenalin reuptake inhibitor (SNRI) - issued a similar black box warning based on a study in which $4 \%$ of children and adolescents taking the drug described suicide ideation compared to 2\% receiving placebo (Wyeth 2003:5). Since October 2004, the United States Food and Drug Administration (FDA) required that all antidepressant medications carry an expanded black-box warning incorporating information about an increased risk of suicidal thinking, feeling and behaviour in children and adolescents (Friedman \& Leon 2007:2343).

Support for the safe and effective use of antidepressants in children and adolescents is diverse and inconsistent. A number of controlled trials support the use of antidepressants over placebo for the treatment of paediatric and adolescent depressive disorders, social phobia, panic disorders, generalised anxiety disorders, and obsessive-compulsive disorder (OCD) (APA 2006:35-157; Bridge et al. 2007:1690; Cotgrove 2007:750); eating disorders (Gowers 2008:331); pre-menstrual dysphoria (Silber \& ValadezMeltzer 2005:523) and nocturnal enuresis (Smellie et al. 1996:62). In addition, antidepressants are used for some clinically accepted off-label indications in paediatric and adolescent patients, such as sleeping disorders (Owens 2006:423; Pelayo \& Dubik 2008:79), headache (Lewis 2002:361), neuropathic pain (Jacob 2004:350), attention deficit hyperactivity disorder (ADHD) (Pliszka 1991:313), autism and Tourette's syndrome (Scahill et al. 2003:1130; APA 2006:157). 
According to a collective expert report by the French National Institute of Health and Medical Research (INSERM 2002), about $5 \%$ of children suffer from some kind of anxiety disorder and 1 to $2 \%$ are hyperactive. They furthermore report that mood disorder increases in adolescence, with 3\% of 13-19-year olds affected. Bulimia nervosa affects $1 \%$ of girls between the ages of 17 and 19. Anorexia affects about $0.2 \%$ of girls between the ages of 15 and 19. Conversely, ADHD occurs more frequently in male children and adolescents than in females, in a ratio of approximately 3:1 (Arnold 1996:555; Gaub \& Carlson 1997:1036). Autism and schizophrenia are much rarer, affecting less than 1\% of children and adolescents (INSERM 2002).

Selective serotonin reuptake inhibitors, in particular fluoxetine, should be considered as first-line treatment in children aged eight years and older (Kastelic, Labellarte \& Riddle 2000:118). Sertraline and fluvoxamine have also been approved for the treatment of paediatric OCD (Geller et al. 2003:1920). No other SSRIs or SNRIs have been expressly registered for the use in major depressive disorders in the under-18s, although they are currently used 'off-label' in Canada, the United Kingdom (UK), Ireland, New Zealand, Australia, the Netherlands and South Africa (World Health Organization 2004:8). Nocturnal enuresis is common in young children but continues in as many as $5 \%$ by 10 years of age (British National Formulary for Children 2008). Drug therapy is not usually appropriate for children under the age of seven years; it can however be used when alternative measures have failed. Tricyclic antidepressants (TCAs) such as amitriptyline, imipramine, and less often nortriptyline can be used. The TCAs are, however, not recommended as firstline treatment in adolescents due to their side-effect profile, which includes cardiotoxicity, a lower seizure threshold and anticholinergic action (Sung \& Kirchner 2000:2303; Murray, de Vries \& Wong 2004:1098). Monoamine oxidase inhibitors (MAOIs) are also not recommended for use in adolescents due to a lack of evidence to support their use and because of dietary restrictions associated with this class of drug (Everett 2002:213). Any antidepressant approved for adult patients can, however, legally be prescribed for children (FDA 2005).

Small but significant numbers of children are taking antidepressants. A sharp increase in the use of psychotropic medicine during the 1990s in American children and adolescents (Olfson et al. 2002:520) included the prescribing of antidepressants to pre-school children, even at the young age of two years (Zito et al. 2000:1026). A New Zealand paper recently reported concerns by medical authorities at figures suggesting antidepressant drugs being prescribed for children aged one and younger $(16.24 \%$ for one-year-olds and $9.58 \%(n=4728)$ for those under one) (Johnston \& McNaughton 2007). There has also been a dramatic increase in the use of antidepressants in the under18 age group in the UK; according to Boseley (2003) there are currently around 50000 children and adolescents taking them. A relatively recent study published in the Pharmacoepidemiological and Drug Safety Journal (Kairuz et al. 2003:379-382) reported a prescribing prevalence of $59 \%$ among 166 adolescents and young adults over a 14-month period in South Africa.

Data pertaining to children and adolescents' psychopharmacology, specifically in South Africa, are limited; with dosages often extrapolated from adult data (Scribante 2005). Clinical observations, nonetheless, suggest that children and adolescents need larger weight-adjusted doses of most medication than do adults due to the shortened half-life of medicine. Dosing with antidepressants among the under-18s should thus start at the lowest possible dose, slowly titrated upwards (Scribante 2005).

In the absence of data on the prescribing patterns of antidepressants among South African children and adolescents, this study aims to investigate these patterns as well as their prevalence in a sub-population of private health care patients below the age of 20 (for the year 2006), with reference to the prescribing frequency and prescribed daily dosage.

\section{SUBJECTS AND METHOD \\ Study design and data source}

A retrospective drug utilisation study design was used to explore the pharmacological treatment of children and adolescents with medicines classified as antidepressants in a section of the private health care sector of South Africa. Data were obtained from a South African pharmaceutical benefit management (PBM) company, which manages the benefits of medical schemes and insurance companies in South Africa by providing a real-time auditing process to claims from pharmacies and other service providers. In 2006, this company performed medicine claim switching for 35 of South Africa's medical schemes. ${ }^{1}$. The claims database sample was therefore considered representative of the average patient served by the private health care sector of South Africa, given his/her choice of medical insurance.

The medicine claims database for 2006 consisted of computerised data on a total number of 996786 claims for a total number of 2370567 dispensed medicine items. The data were obtained directly from the central database of the PBM; therefore no forthright manipulation of the data by the researchers was possible. It was assumed that all data were reliable and valid. The datasets were however verified by testing for outlying data, as well as by performing random data checks.

The database provided information about the drug's trade name, the NAPPI-code (such as, type of medication and strength/ concentration), the date the prescription was filled, prescription number, patient dependant-, physician-, pharmacy- and medical scheme identification numbers, and the number of the medicine items prescribed. Unique encrypted numbers were used to prohibit the identification of the patient, thus maintaining anonymity.

Certain limitations that could limit the scope of the study were identified, namely the lack of detailed clinical data (such as diagnosis or medical history) and certain demographic data (such as weight or body mass index) as well as the duration of treatment or number of days' supply of medicine items. The relevance of some utilisation patterns and prescribed daily dosages could therefore not be determined. External validity was also limited, implying that the results of the study can be generalised to the specific database and study population only. The practical justification of using this database included the fact that the claims database employed in this study was electronically available and accessible. Claims not submitted through the PBM (such as patients who paid cash for their medication and/or were not members of a medical scheme) were thus excluded from the study.

Permission to conduct the study was granted by the PBM and the North-West University's ethics committee.

\section{Study population and measurements}

The study population consisted of children and adolescents aged 19 years and younger who filled at least one prescription for an antidepressant during a 12-month period (1 January 2006 to 31 December 2006). Information for all medicine claims records for this period was obtained. Antidepressant medicine usage was analysed according to four patient age strata: children younger than 5 years and $5 \leq 9$ years, and adolescents $9 \leq 15$ years and $15 \leq 19$ years.

The study population represented $17.5 \%(\mathrm{n}=996786)$ of the total number of prescriptions, and $18.5 \%(n=2370567)$ of the number of medicine items dispensed on the database for $2006^{2}$.

1.South Africa has about 160 medical schemes totaling around seven million

beneficiaries; of which only about 40 are open to the public (Insurance Za 2008).

2.A prescription in South Africa can contain more than one medicine item. 
TABLE 1

Therapeutic dosing standards of antidepressants for children and adolescents

\begin{tabular}{|c|c|c|c|c|c|}
\hline & \multicolumn{5}{|c|}{ DAILY DOSAGE (mg/day) } \\
\hline & $0 \leq 5$ YEARS & $5 \leq 9$ YEARS & $9 \leq 15$ YEARS & $15 \leq 19$ YEARS & $\operatorname{MAX}^{y}$ \\
\hline Amitriptyline & $25^{\mathrm{a}}$ & $10-20$ & $25-50$ & 50 & 200 \\
\hline Amitriptyline/chlordiazepoxide & - & - & - & - & - \\
\hline Amoxapine & - & - & $100-150$ & $100-150$ & 300 \\
\hline Bupropion & - & - & - & - & - \\
\hline Citalopram & - & - & $8-10^{\#}$ & 20 & 60 \\
\hline Clomipramine & 10 & $10-20$ & $20-50$ & 50 & 200 \\
\hline Dosulepin & - & - & - & - & - \\
\hline Dothiepin & - & - & - & - & - \\
\hline Duloxetine & - & - & - & - & - \\
\hline Escitalopram & - & - & - & - & - \\
\hline Fluoxetine & - & - & - & $10-20$ & 40 \\
\hline Flupenthixol & - & - & - & - & - \\
\hline Fluphenazine/nortriptyline & - & - & - & - & - \\
\hline Fluvoxamine & - & - & $25-200$ & $25-200$ & 200 \\
\hline Imipramine & - & $20-30$ & $25-50$ & $25-75$ & 75 \\
\hline Lithium & - & - & $1000-1500^{\#}$ & $1000-1500^{\#}$ & 1500 \\
\hline Lofepramine & - & - & - & - & - \\
\hline Maprotiline & - & - & - & - & - \\
\hline Mianserin & - & - & - & - & - \\
\hline Mirtazipine & - & - & - & - & - \\
\hline Moclobemide & - & - & - & - & - \\
\hline Nortriptyline & - & 10 & $10-20$ & $25-50$ & 150 \\
\hline Paroxetine & - & - & - & - & - \\
\hline Reboxetine & - & - & - & - & - \\
\hline Sertraline & - & - & $25-50$ & 50 & 200 \\
\hline Sulpiride & - & - & - & $150-460$ & $<460$ \\
\hline Tranylcypromine & - & - & - & - & - \\
\hline Trazodone & - & $75-100^{*}$ & $75-100^{*}$ & $75-100^{*}$ & $<310$ \\
\hline Trimipramine & - & - & $50-100$ & $50-100$ & 100 \\
\hline Venlafaxine & - & - & - & - & - \\
\hline \multicolumn{6}{|c|}{$\begin{array}{l}\text { The following references were used during construction of this table: Snyman (2006:16-35); Gibbon (2003:440-450); Malahyde Information Systems (2008), the British National } \\
\text { Formulary for Children (2008), Sweetman (2008), and Centers for Disease Control and Prevention (2000). }\end{array}$} \\
\hline \multicolumn{6}{|c|}{ Areas were denoted as '-' when none of the references clearly stated a dosage for the age group (see study population and measurements). } \\
\hline \multicolumn{6}{|c|}{ yaximum permissible daily dosage in $\mathrm{mg} /$ day. } \\
\hline \multicolumn{6}{|c|}{ a Children aged 2 to 12 years (for the treatment of pain). } \\
\hline \multicolumn{6}{|c|}{ \# Children above the age of 12 years. } \\
\hline $\begin{array}{l}\text { * Calculated using the } 50 \text { th perc } \\
\text { nearest decimal. }\end{array}$ & intiles for boys & $2-20$ years $(C$ & for Disease Con & Prevention 2000), & off to the \\
\hline
\end{tabular}

Assessment of treatment with antidepressants in children and adolescents included measures of the prescribing frequency of the antidepressant and prescribed daily dosages. Antidepressant medications were identified on the basis of a list of medications used by South African health care professionals (that is the Monthly Index of Medical Specialties, or MIMS, 2006) (Snyman 2006:16-35). Medicines were assigned to one of seven classes: tricyclic, non-tricyclic, mono-amine oxidase inhibitors, selective serotonin reuptake inhibitors, serotonin and noradrenaline reuptake inhibitors, lithium, and others (such as reboxetine, sulpiride, flupenthixol, trazodone, fluphenazine, and mirtazapine). NAPPI-codes were used to identify each antidepressant item on the database according to product name, package size, and strength/concentration (Snyman 2006:4).

'Medication use' was defined as having at least one prescription claim for an antidepressant during the study period. The prescribed daily dosage (PDD) was used to determine sub-therapeutic as well as higher than optimal doses of antidepressants in the study population by measuring the average number of tablets prescribed as well as the average strength that a patient received per day. 'Sub-therapeutic dosing' was defined as receiving doses lower than therapeutic dosing standards and 'higher than optimal doses' was defined as exceeding therapeutic dosing standards.

The therapeutic dosing range for children and adolescents was compiled from indications specified in MIMS (Snyman 2006:1635); the South African Medicines Formulary (Gibbon 2003:440450); the South African Electronic Package Inserts (Malahyde Information Systems 2008), the British National Formulary for Children (2008) and the Martindale (Sweetman 2008). The optimal age-based therapeutic dosing range for trazodone was calculated using the 50th percentile on the average weight-forage percentiles for children aged two to 20, as determined by the growth charts of the Centers for Disease Control and Prevention (CDC) (Centers for Disease Control and Prevention, n.d.). The resulting therapeutic daily dosing range for children and adolescents is depicted in Table 1. 
TABLE 2

Frequency of the prescribed active ingredients on the database, $\mathrm{n}(\%)$

\begin{tabular}{|c|c|c|c|c|}
\hline & \multicolumn{4}{|c|}{ FREQUENCY OF PRESCRIBED ACTIVE INGREDIENTS $(n=2300)$} \\
\hline & $0 \leq 5$ YEARS & $5 \leq 9$ YEARS & $9 \leq 15$ YEARS & $15 \leq 19$ YEARS \\
\hline Amitriptyline $10 \mathrm{mg}$ & $31(1.35)$ & $47(2.04)$ & $119(5.17)$ & $58(2.52)$ \\
\hline Amitriptyline $25 \mathrm{mg}$ & $5(0.22)$ & $26(1.13)$ & $84(3.65)$ & $66(2.87)$ \\
\hline Clomipramine $10 \mathrm{mg}$ & - & $2(0.87)$ & $4(0.17)$ & - \\
\hline Clomipramine $25 \mathrm{mg}$ & - & - & $9(0.39)$ & $2(0.87)$ \\
\hline Clomipramine $75 \mathrm{mg}$ & - & - & $3(0.13)$ & - \\
\hline Dothiepin $25 \mathrm{mg}$ & - & - & $3(0.13)$ & $8(0.35)$ \\
\hline Imipramine 10 mg & $7(0.30)$ & $94(4.09)$ & $114(4.96)$ & $10(0.43)$ \\
\hline Imipramine 25 mg & $6(0.26)$ & $67(2.91)$ & $186(8.09)$ & $23(1)$ \\
\hline Lofepramine $70 \mathrm{mg}$ & - & - & - & $7(0.30)$ \\
\hline Trimipramine $25 \mathrm{mg}$ & - & - & $1(0.04)$ & - \\
\hline Trimipramine $50 \mathrm{mg}$ & $1(0.04)$ & - & - & - \\
\hline Moclobemide $150 \mathrm{mg}$ & - & - & $1(0.04)$ & $3(0.13)$ \\
\hline Moclobemide $300 \mathrm{mg}$ & - & - & - & $1(0.04)$ \\
\hline Citalopram 10 mg & $12(0.52)$ & $23(1)$ & $113(4.91)$ & $148(6.43)$ \\
\hline Escitalopram $10 \mathrm{mg}$ & - & $2(0.87)$ & $22(0.96)$ & $72(3.13)$ \\
\hline Fluoxetine 20 mg & $8(0.35)$ & $11(0.48)$ & $74(3.22)$ & $182(7.91)$ \\
\hline Fluoxetine $40 \mathrm{mg}$ & - & - & $8(0.35)$ & $2(0.87)$ \\
\hline Fluvoxamine $100 \mathrm{mg}$ & - & $10(0.43)$ & $19(0.83)$ & $24(1.04)$ \\
\hline Paroxetine $12.5 \mathrm{mg}$ & - & - & $8(0.35)$ & $10(0.43)$ \\
\hline Paroxetine $20 \mathrm{mg}$ & $3(0.13)$ & $9(0.39)$ & $49(2.13)$ & $68(2.96)$ \\
\hline Paroxetine $25 \mathrm{mg}$ & - & $1(0.04)$ & - & - \\
\hline Paroxetine $30 \mathrm{mg}$ & - & - & - & $4(0.17)$ \\
\hline Sertraline 50 mg & - & $2(0.87)$ & $57(2.48)$ & $48(2.09)$ \\
\hline Duloxetine $30 \mathrm{mg}$ & - & - & - & $16(0.70)$ \\
\hline Duloxetine $60 \mathrm{mg}$ & - & $1(0.04)$ & - & $25(1.09)$ \\
\hline Venlafaxine $75 \mathrm{mg}$ & $2(0.87)$ & $7(0.30)$ & $7(0.30)$ & $48(2.09)$ \\
\hline Venlafaxine $150 \mathrm{mg}$ & - & - & - & $10(0.43)$ \\
\hline Lithium $250 \mathrm{mg}$ & - & - & $1(0.04)$ & - \\
\hline Lithium $450 \mathrm{mg}$ & $7(0.30)$ & - & - & - \\
\hline Bupropion $150 \mathrm{mg}$ & $17(0.74)$ & $9(0.39)$ & $4(0.17)$ & $4(0.17)$ \\
\hline Flupenthixol $0.25 \mathrm{mg}$ & - & - & $2(0.87)$ & \\
\hline Flupenthixol $0.5 \mathrm{mg}$ & - & - & - & $13(0.57)$ \\
\hline Fluphenazine/nortriptyline 0.5 / $10 \mathrm{mg}$ & $1(0.04)$ & - & - & - \\
\hline Mirtazapine $15 \mathrm{mg}$ & - & - & - & $6(0.26)$ \\
\hline Mirtazapine $30 \mathrm{mg}$ & - & - & - & $11(0.48)$ \\
\hline Reboxetine $4 \mathrm{mg}$ & - & - & - & $1(0.04)$ \\
\hline Sulpiride $50 \mathrm{mg}$ & $5(0.22)$ & $5(0.22)$ & $28(1.22)$ & $40(1.74)$ \\
\hline Sulpiride Elixir $25 \mathrm{mg} / 5 \mathrm{ml}$ & $12(0.52)$ & $1(0.04)$ & $5(0.22)$ & $1(0.04)$ \\
\hline Sulpiride Forte $200 \mathrm{mg}$ & - & $1(0.04)$ & - & $1(0.04)$ \\
\hline Trazodone $50 \mathrm{mg}$ & $1(0.04)$ & $1(0.04)$ & $3(0.13)$ & $19(0.83)$ \\
\hline Trazodone $100 \mathrm{mg}$ & $7(0.30)$ & - & - & $1(0.04)$ \\
\hline TOTAL & $125(5.43)$ & $319(13.87)$ & $924(40.17)$ & 932 (40.52) \\
\hline
\end{tabular}

\section{Data analysis}

Basic descriptive statistics, for example, frequencies, the arithmetic mean (average) and the PDD were used to characterise the study sample, and were calculated using the Statistical Analysis System ${ }^{\circledR}$ SAS for Windows $9.1^{\circledR}$ program (SAS Institute Inc. 2002-2003).

The PDD was calculated as the number of milligrams dispensed (quantity prescribed multiplied by the strength or concentration per unit) divided by the days' supply. (For the purpose of this study, a month consisted of 30 days.)

\section{RESULTS}

Patient characteristics and general prescribing patterns

Table 2 tabulates the number of prescriptions by age group; a total of 234 children nine years and younger, and 779 adolescents aged 10-19 years received a total of 444 and 1856 prescriptions for an antidepressant during the study period. The mean number of antidepressant prescriptions per patient per year was 2.88 (SD 3.04). 


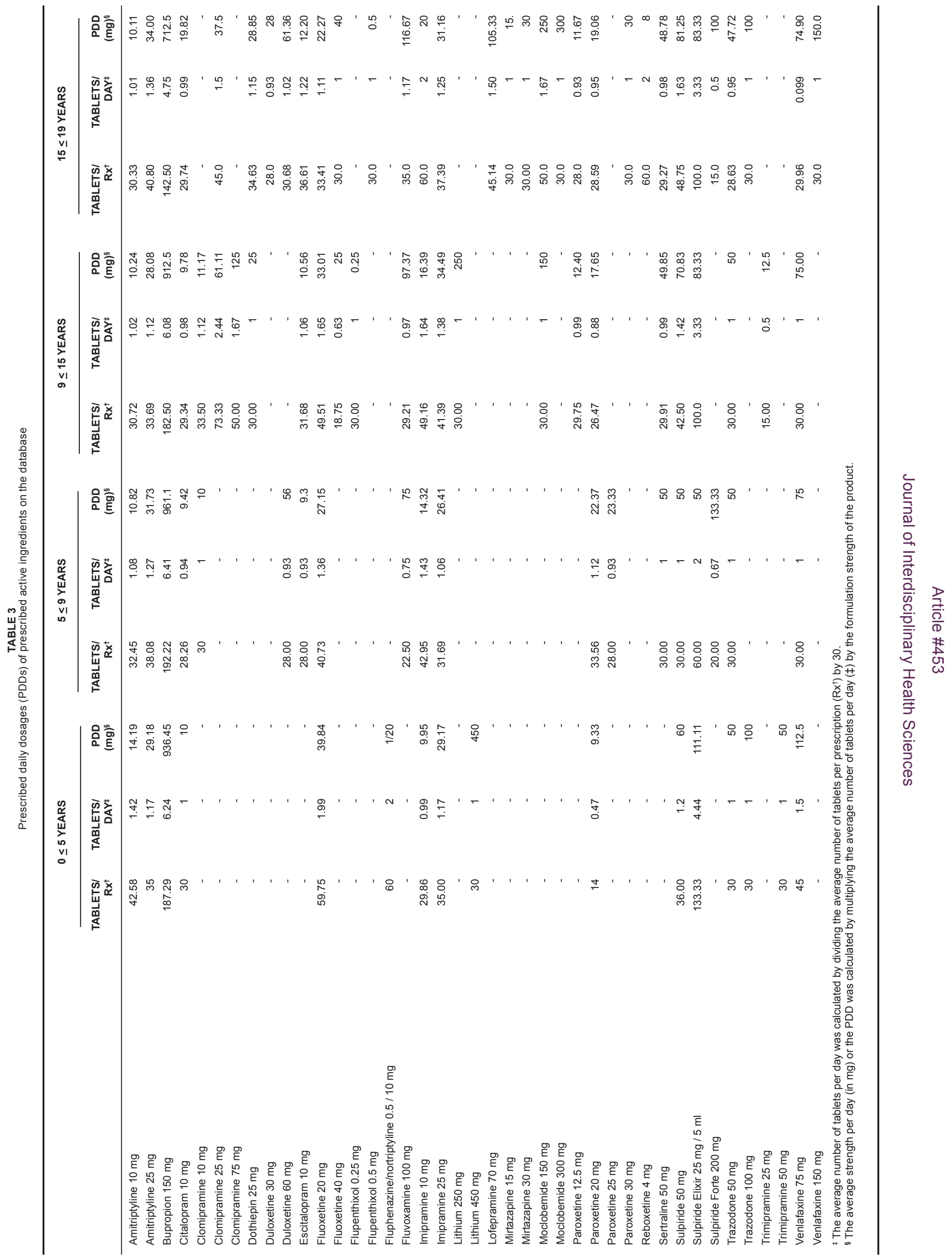


About $28 \%$ of the study population was female, compared to $26 \%$ males (sex was not recorded for $46.3 \%$ of patients). In patients aged $9 \leq 15$ years, antidepressant use was 1.4 times more common in males than females, compared with a $7: 4$ female:male ratio in those aged $16-19$ years.

The most commonly prescribed pharmacological groups of antidepressants were the SSRIs $(43.0 \%)$ and the TCAs $(42.7 \%)$ (see Table 2). The most commonly prescribed antidepressant drugs were imipramine (21.6\%) and amitriptyline (19\%). SNRIs accounted for 116 prescriptions $(5.0 \%)$, whereas sulpiride accounted for $99(4.3 \%)$ prescriptions.

In the age group younger than five years, the most frequently prescribed antidepressant was amitriptyline, accounting for $28.8 \%(\mathrm{n}=125)$ of the medicine items prescribed in this age group. The second most often prescribed antidepressants in this group were bupropion (13.6\%) and sulpiride (13.6\%) (see Table $2)$. About $18 \%(\mathrm{n}=125)$ of prescribed medicines in this group were for SSRIs, such as citalopram (52.2\%), fluoxetine (34.8\%), and paroxetine $(13 \%)$. Further investigation revealed that about $11 \%(n=125)$ of the antidepressant prescriptions in this age group were for patients below the age of three years. This included six prescriptions issued to children between the ages of 24 and 36 months (containing inter alia fluoxetine $20 \mathrm{mg}$ and bupropion $150 \mathrm{mg}$ ), and seven prescriptions to children between 12 and 24 months (containing inter alia bupropion $150 \mathrm{mg}$ ethipramine $25 \mathrm{mg}$, trimipramine $50 \mathrm{mg}$, citalopram $10 \mathrm{mg}$, and sulpiride $25 \mathrm{mg} / 5 \mathrm{ml}$ ). The youngest patient on the database that received an antidepressant prescription was six weeks old (sulpiride $50 \mathrm{mg}$ ).

The tricyclic antidepressant imipramine presented as the most prescribed active ingredient in the age group $5 \leq 9$ years $(50.5 \%$; $\mathrm{n}=319)$; followed by amitriptyline $(22.9 \%, \mathrm{n}=319)$.

Prescriptions to patients in the age group $9 \leq 15$ years formed the largest percentage of the study population $(40.2 \%, n=2300)$. The pharmacological group mostly prescribed to this age group proved to be the tricyclic antidepressants $(22.7 \%, \mathrm{n}=2300)$, in particular imipramine $(32.5 \%, \mathrm{n}=924)$ and amitriptyline $(22.0 \%$, $\mathrm{n}=924)$, followed by the SSRIs $(15.2 \%, \mathrm{n}=2300)$, in particular citalopram $(32.3 \%, \mathrm{n}=350)$ and fluoxetine $(23.4 \%, \mathrm{n}=350)$.

Patients aged 16 to 19 years received about $41 \%(n=2300)$ of prescriptions in the study population. The pharmacological group that includes the SSRIs and tricyclic antidepressants was prescribed most often in this age group $(59.9 \%$ and $18.7 \%, \mathrm{n}=$ 932). The most prescribed antidepressant item in this age group was fluoxetine $(19.7 \%)$ followed by citalopram $(15.9 \%, n=932)$.

\section{Prescribed daily dosages}

Antidepressants are rarely prescribed to children younger than five years, and if so, only in small dosages (DeBar et al. 2003:150; Martin et al. 2003:72) (that is, amitriptyline and clomipramine for the treatment of pain-related conditions, depression, and cataplexy associated with narcolepsy and OCD) (see Table 1). The PDD calculated for amitriptyline (that is $29.18 \mathrm{mg}$ ) was slightly higher than the maximum recommended daily dosage for the treatment of pain in children aged $2-12$, which is $20-25 \mathrm{mg} /$ day (see Table 1). Results further showed a number of antidepressants prescribed to this age group that are not recommended for use in children and adolescents, such as, bupropion, citalopram, fluoxetine, fluphenazine/nortriptyline, imipramine, lithium, paroxetine, sulpiride, trazodone, trimipramine, and venlafaxine (see Table 1). The PDDs for all of these antidepressants were higher than those recommended for older children (that is children above the age of five).

Children between ages $5 \leq 9$ years also received a number of antidepressants not recommended or indicated for use in this age group, for example, bupropion, citalopram, duloxetine, escitalopram, fluoxetine, fluvoxamine, imipramine, paroxetine, sertraline, sulpiride, and venlafaxine (see Table 1). The PDD calculated for amitriptyline $25 \mathrm{mg}$ (that is $31.73 \mathrm{mg}$ ) was higher than the maximum recommended daily dosage for this medicine in this specific age group, which is $20 \mathrm{mg} /$ day.

Adolescents $9 \leq 15$ years again received a number of antidepressants not recommended or indicated for use in this age group, for example, bupropion, dothiepin, escitalopram, fluoxetine, moclobemide, paroxetine, and venlafaxine (see Table 1). The PDDs calculated for clomipramine $25 \mathrm{mg}$ and $75 \mathrm{mg}$ (that is $61.11 \mathrm{mg}$ and $125 \mathrm{mg}$, respectively) were higher than the maximum recommended daily dosages for this medicine, which is $50 \mathrm{mg} /$ day. PDDs calculated for some of the antidepressant medicines that were on average below the recommended minimum daily dosages included lithium (250 $\mathrm{mg} /$ day compared to the recommended $1000-1500 \mathrm{mg} /$ day for the treatment of depression or $300-400 \mathrm{mg} /$ day for prophylaxis) and trimipramine $25 \mathrm{mg}(12.5 \mathrm{mg} /$ day compared to the recommended $50-100 \mathrm{mg} /$ day). Trazodone $50 \mathrm{mg}$ had a PDD of $50 \mathrm{mg}$ /day compared to the recommended $75-100 \mathrm{mg} /$ day for adolescents (calculation based on using the 50th percentile on the average weight-for-age percentiles for children aged 2-20).

Adolescents aged $15 \leq 19$ years yet again received a number of antidepressants not recommended or indicated for use in this age group, for example, bupropion, dothiepin, duloxetine, escitalopram, flupenthixol, lofepramine, mirtazapine, moclobemide, paroxetine, reboxetine, and venlafaxine (see Table 1). Calculated PDDs were not above the maximum recommended daily dosages for patients in this age group, but a number of items were prescribed at doses far below those recommended for this age group, for example, sulpiride (81.25-100 mg/day) compared to the recommended $150-460 \mathrm{mg} /$ day.

\section{DISCUSSION}

In the absence of data on the prescribing patterns of antidepressants among South African children and adolescents, this study aimed to investigate these as well as their prevalence in a sub-population of private health care patients below the age of 20, with reference to prescribing frequency and prescribed daily dosage. There are five key findings.

Firstly, the results of this study show that females receive more prescriptions for antidepressants than their male counterparts, with the highest prevalence in the $15 \leq 19$ year age group (sex was, however, only recorded in about $54 \%$ of the study population). According to Gelder, Mayou and Geddes (1999:137), females have a higher risk for developing depression relative to males and the prevalence for major depressive disorders in Western countries is $40-90$ per 1000 females compared to $20-30$ per 1000 males. Weisman and Jensen (Ladikos 2003:4) report that the incidence of major depressive disorder (MDD) increases in children particularly before puberty, with a peak age of onset between 15 and 20 years of age. Research indicates that a number of other ailments also become more common and frequent during adolescence; inter alia headaches and premenstrual dysphoric disorder. The latter disorder, described as 'a periodic, recurrent, debilitating condition with severe psychological or effective symptoms during the late luteal phase', also often begins during adolescence in females (Silber \& Valadez-Meltzer 2005:518). According to Deubner (1977:173) one third of children age seven years, and half of those at least 15 years of age have headaches. Boys are frequently more affected than girls before the onset of puberty, and thereafter headaches occur more frequently in girls. Using antidepressants as a proxy for identifying ailments in a prescription claims database should however be done with caution and, when possible, in combination with clinical data, the latter of which lacked in this study.

Secondly, the most commonly prescribed pharmacological groups of antidepressants were the TCAs (42.7\%) and SSRIs 
(43.0\%). The British National Formulary for Children (2008) states that the choice of antidepressant should be based on the individual child's requirements, including the 'presence of concomitant disease, existing therapy, suicide risk, and previous response to "antidepressant" therapy'. The TCAs have had a substantial role in the pharmacotherapy of children and adolescents over the past three decades (Daly \& Wilens 1998:1123). Efficacy has been established in the treatment of enuresis (Canadian Paediatric Society 2005); OCD (in particular clomipramine) (The Clomipramine Collaborative Study Group 1991); and ADHD in children and adolescents (Banaschewski et al. 2004; Woodruff et al. 2004). According to Murray, Wong and de Vries (2004:524), SSRIs have also become more popular in this population in the past decade. This may be because SSRIs have been generally accepted for a number of years in the treatment of adult depressive disorders, and the safety of TCAs in the paediatric setting has become more of a concern (Wilens et al. 1996:1491; Hazell et al. 2002:CD002317). The SSRIs (in particular fluoxetine, sertraline, paroxetine, fluvoxamine, citalopram, and escitalopram) are the drugs of choice for the treatment of OCD, bulimia nervosa, premenstrual dysphoric disorder, posttraumatic stress disorder, social phobia, panic disorder and generalised anxiety disorder in adolescents (Ables \& Baughman 2003:548). Again, using antidepressants as a proxy for identifying ailments in patients in a prescription claims database should be done with vigilance.

Thirdly, the most commonly prescribed antidepressant drugs were imipramine and amitriptyline. Imipramine was one of the first pharmacotherapies successfully used for the pharmacological management of nocturnal enuresis in distressed, older children if other treatments had been unsuccessful or were contraindicated (Canadian Paediatric Society 2005). According to Perry et al. (2006:183) imipramine is also considered the drug of choice for the treatment of cataleptic episodes associated with narcolepsy. Amitriptyline is considered the drug of choice in the treatment for episodic and chronic tension-type headache in older children and adolescents (Tagliente, Ruju \& Pascotto 2004:1129).

Fourthly, a large number of antidepressants not registered for use in children and adolescents are being prescribed in this subpopulation of South African private health care patients below the age of 20, including drugs such as bupropion, duloxetine, mirtazipine, moclobemide, paroxetine, and venlafaxine. This included antidepressants being prescribed to children between the ages of six weeks to 36 months. The relevance of these prescribing patterns could again not be determined as the prescriber's indication for treatment was not available on the database. This finding is, however, a well-documented problem worldwide in paediatric, adult and geriatric populations (Ma, Lee \& Stafford 2005:441; Rosack 2006:16; Zullino, Schwartz, Bilancioni \& Baumann 2008:23).

Finally, the majority of drugs were also prescribed at daily dosages higher than recommended for treatment in paediatric and adolescent populations. The relevance of these prescribing patterns could again not be determined as the prescriber's indication for treatment was not available on the database; and information regarding the patient's weight lacked.

\section{CONCLUSION}

This study highlighted the most commonly prescribed antidepressants within a sub-population of South African children and adolescents. The relevance of certain prescribing/ utilisation patterns could not be determined as individual clinical data (such as weight or body mass index) and the prescriber's indication for treatment were not available on the database. A point of concern is the off-label prescribing among children and adolescents. Insight into the underlying reasons for these drugs being prescribed and their appropriateness is needed to determine the rationality thereof within the South African context.

\section{ACKNOWLEDGEMENTS}

The study has been partly supported by a National Research Foundation (NRF) Grant. The author wishes to thank the South African Pharmaceutical Benefit Management (PBM) company that provided this data. The interpretation of the results does not necessarily reflect that of the NRF or the PBM. We are also grateful to Ms A. Bekker for assisting in the data analysis and Prof. J.C. Breytenbach and Ms M. Terblanche for assisting in proofreading the article.

\section{REFERENCES}

Ables, A.Z. \& Baughman, O.L., 2003, 'Antidepressants: Update on new agents and indications', American Family Physician 67(3), 547-554.

APA Working Group on Psychoactive Medications for Children and Adolescents, 2006, Psychopharmacological, psychosocial, and combined interventions for childhood disorders: Evidence base, contextual factors, and future directions, American Psychological Association Washington DC.

Arnold, L.E., 1996, Sex differences in ADHD: Conference summary. Journal of Abnormal Child Psychology 24, 555-569.

Banaschewski, T., Roessner, V., Dittmann, R.W., Santosh, P.J. \& Rothenberger, A., 2004, 'Non-stimulant medications in the treatment of ADHD', European Child and Adolescent Psychiatry 13(S1), i102-i116.

Boseley, S., 2003, 50,000 children taking antidepressants, viewed 1 September 2008, from http://www.guardian.co.uk/uk_news/ story/0,3604,1045902,00.html.

Bridge, J.A., Iyengar, S., Salary, C.B., Barbe, R.P., Birmaher, B., Pincus, H.A. et al., 2007, 'Clinical response and risk for reported suicidal ideation and suicide attempts in pediatric antidepressant treatment: A meta-analysis of randomized controlled trials', The Journal of the American Medical Association 297(15), 1683-1696.

British National Formulary for Children, 2008, Antidepressant drugs, viewed 1 September 2008, from http://www. medicinescomplete.com/mc/bnfc/current/.

Canadian Paediatric Society, 2005, 'Management of primary nocturnal enuresis', Paediatrics $\mathcal{E}$ Child Health 10(10), 611614.

Centers for Disease Control and Prevention, 2000, 2000, CDC Growth Charts: United States, viewed 1 September 2008, from http://www.cdc.gov/growthcharts.

Cotgrove, A., 2007, 'Should young people be given antidepressants? Yes', British Medical Journal 335(7623), 750.

Daly, J.M. \& Wilens, T., 1998, 'The use of tricyclic antidepressants in children and adolescents', Pediatric Clinics of North America 45(5), 1123-1135.

Debar, L.L., Lynch, F., Powell, J. \& Gale, J., 2003, 'Use of psychotropic agents in preschool children: Associated symptoms, diagnoses, and health care services in a health maintenance organization', Archives of Pediatrics and Adolescent Medicine 157(2), 150-157.

Deubner, D.C., 1977, 'An epidemiological study of migraine and headache in 10-20 year olds', Headache 17, 173-80.

Everett, A.V., 2002, 'Pharmacologic treatment of adolescent depression', Current Opinion in Pediatrics 14(2), 213-218.

Friedman, R.A. \& Leon, A.C., 2007, 'Expanding the black box - depression, antidepressants, and the risk of suicide', The New England Journal of Medicine 356(23), 2343-2346.

Gaub, M. \& Carlson, C.L., 1997, 'Gender differences in ADHD: A meta-analysis and critical review', Journal of the American Academy of Child E Adolescent Psychiatry 36, 1036-1045.

Gelder, M., Mayou, R. \& Geddes, J., 1999, Psychiatry, Oxford University Press, New York.

Geller, D.A., Biederman, J., Stewart, S.E., Mullin, B., Martin, A., Spencer, T. et al., 2003, 'Which SSRI? A meta-analysis of pharmacotherapy trials in pediatric obsessive-compulsive disorder', The American Journal of Psychiatry 160(12), 19191928.

Gibbon, C.J., 2003, South African Medicines Formulary, South African Medical Association, Pinelands. 
Gowers, S.G., 2008, 'Management of eating disorders in children and adolescents', Archives of Disease in Childhood 93, 331-334

Hazell, P., O'Connell, D., Heathcote, D. \& Henry, D., 2002, 'Tricyclic drugs for depression in children and adolescents', Cochrane Database of Systematic Reviews 2, CD002317.

Insurance Za., 2008, Medical Schemes South Africa, viewed September 2009, from available at: http://www. medicalscheme.co.za.

ISERM, 2002, Mental disorders: Screening and prevention on children and adolescents, Institute National de la Santé et de la Recherché Médicale, Paris.

Jacob, E., 2004, 'Neuropathic pain in children with cancer', Journal of Pediatric Oncology Nursing 21(6), 350-357.

Johnston, M. \& Mcnaughton, M., 2007, Antidepressants given to babies, viewed 1 September 2008, from http://www.nzherald.co.nz/section/1/print.cfm?c_ id=1\&objectid=10462684\&pnum $=0$.

Kairuz, T., Truter, I., Hugo, J. \& Foxcroft, C., 2003, 'Prescribing patterns of tricyclic and selective reuptake inhibitor antidepressants among a sample of adolescents and young adults', Pharmacoepidemiology and Drug Safety 12(5), 379-382.

Kastelic, E.A., Labellarte, M.J. \& Riddle, M.A., 2000, 'Selective serotonin reuptake inhibitors for children and adolescents', Current Psychiatry Reports 2, 117-123.

Ladikos, A., 2003, 'Depression in childhood and adolescence', Serenity: Anxiety and Depression - A Positive Outlook 1(1), 4-5.

Lewis, D.W., 2002, 'Headaches in children and adolescents', American Family Physician 65, 625-632; 635-636.

Ma, J., Lee, K.V. \& Stafford, R.S., 2005, 'Depression treatment during outpatient visits by U.S. children and adolescents', Journal of Adolescent Health 37, 434-442.

Malahyde Information Systems, 2008, South African electronic package inserts, viewed 1 September 2008, from http:// www.home.intekom.com/pharm/.

Martin, A., Van Hoof, T., Stubbe, D., Sherwin, T. \& Scahill, L. 2003, 'Multiple psychotropic pharmacotherapy among child and adolescent enrollees in Connecticut Medicaid managed care', Psychiatric Services 54(1), 72-77.

Murray, M.L., De Vries, C.S. \& Wong, I.C.K., 2004, 'A drug utilisation study of antidepressants in children and adolescents using the General Practice Research Database', Archives of Disease in Childhood 89, 1098-1102.

Murray, M.L., Wong, I.C.K. \& De Vries, C.S., 2004, 'Treating major depression in children and adolescents: Research is needed into safer and more effective drugs', British Medical Journal 328(7438), 524-525.

Olfson, M., Marcus, S.C., Weissman, M.M. \& Jensen, P.S., 2002, 'National trends in the use of psychotropic medications by children', Journal of the American Academy of Child $\mathcal{E}$ Adolescent Psychiatry 41(5), 514-521.

Owens, J.A., 2006, 'Pediatric insomnia', Sleep Medicine Clinics $1(3), 423-435$.

Pelayo, R. \& Dubik, M., 2008, 'Pediatric sleep pharmacology', Seminars in Pediatric Neurology 15, 79-90.

Perry, P.J., Alexander, B., Liskow, B.I. \& Devane, L.C., 2006, Psychotropic drug handbook, Lippincott Williams \& Wilkins, Philadelphia.

Pliszka, S.R., 1991, 'Antidepressants in the treatment of child and adolescent psychopathology', Journal of Clinical Child Psychology 20(3), 313-321.

Rosack, J., 2003, 'FDA warns of suicide risk with paroxetine', Psychiatric News 38(14), 1-37.

Rosack, J., 2006, 'Off-label psychotropic use reveals complex patterns', Psychiatric News 41(14), 16.
SAS FOR WINDOWS 9.1. 2005. SAS Institute Inc., 2002-2003.

Scahill, L., Leckman, J.F., Schultz, R.T., Katsovich, L. \& Peterson, B.S., 2003, 'A placebo-controlled trial of risperidone in Tourette syndrome', Neurology 60, 1130-1135.

Scribante, L., 2005, Antidepressants in children and adolescents scientifically considered, viewed 1 September 2009, from http://www.sasop.co.za/D_patientdeu_T_F_020.asp.

Silber, T.J. \& Valadez-Meltzer, A., 2005, 'Premenstrual dysphoric disorder in adolescents: Case reports of treatment with fluoxetine and review of the literature', Journal of Adolescent Health 37, 518-525.

Smellie, J.M., McGrigor, V.S., Meadow, S.R., Rose, S.J. \& Douglas, M.F., 1996, 'Nocturnal enuresis: A placebo controlled trial of two antidepressant drugs', Archives of Disease in Childhood 75(1), 62-66.

Snyman, J.R., 2006, MIMS Monthly Index of Medical Specialities, Ultro-Litho, Pretoria.

Sung, S.E. \& Kirchner, J.T., 2000, 'Depression in children and adolescents', American Family Physician 62(10), 2297-2312.

Sweetman, S., 2008, Martindale: The Complete Drug Reference, viewed 1 September 2008, from http://www. medicinescomplete.com/mc/martindale/current/.

Tagliente, F., Ruju, F.M. \& Pascotto, A., 2004, 'Treatment of episodic and chronic tension-type headache in children and adolescents', The Journal of Headache and Pain 5(S2), 1129 2369.

The Clomipramine Collaborative Study Group, 1991, 'Clomipramine in the treatment of patients with obsessivecompulsive disorder', Archives of General Psychiatry 48, 730738.

United States Food and Drug Administration, 2003, FDA Issues public health advisory entitled: Reports of suicidality in pediatric patients being treated with antidepressant medications for major depressive disorder (MDD), viewed 2 September 2008, from http://www.fda/bbs/topics/ANSWERS/2003/ANS01256. html.

United States Food and Drug Administration, 2005, Antidepressant use in children, adolescents, and adults, viewed 1 September 2008, from http://www.fda.gov/cder/drug/ antidepressants/default.htm.

Wilens, T.E., Biederman, J., Baldessarini, R.J., Geller, B., Schleifer, D., Spencer, T.J., Birmaher, B. et al., 1996, 'Cardiovascular effects of therapeutic doses of tricyclic antidepressants in children and adolescents', Journal of the American Academy of Child E Adolescent Psychiatry 35(11), 1491-1501.

Woodruff, T.J., Axelrad, D.A., Kyle, A.D., Nweke, O., Miller, G.G. \& Hurley, B.J., 2004, 'Trends in environmentally related childhood illnesses', Pediatrics 113, 1133-1140.

World Health Organization, 2004, 'Selective serotonin reuptake inhibitors (SSRIs): Use in children with major depressive disorder', WHO Pharmaceuticals Newsletter 3, 8-10.

Wyeth, 2003, Effexor ${ }^{\circledR}$ (venlafaxine hydrochloride) tablets, Wyeth Pharmaceuticals, Philadelphia.

Zito, J.M., Safer, D.J., Dosreis, S., Gardner, J.F., Boles, J. \& Lynch, F., 2000, 'Trends in prescribing of psychotropic medication in preschoolers', Journal of the American Medical Association 283(8), 1025-1030.

Zullino, D.F., Schwartz, B., Bilancioni, R. \& Baumann, P., 2008, 'Off-label utilization of antidepressants', Acta Medica 51(1), 19-24. 